\title{
Design of a Participatory Web-Based Geographic Information System for Determining Industrial Zones
}

\author{
Endang Chumaidiyah $\mathbb{D}^{1},{ }^{1}$ Mouli De Rizka Dewantoro $\mathbb{D}^{1},{ }^{1}$ and Anton Abdulbasah Kamil $\mathbb{i D}^{2}$ \\ ${ }^{1}$ Telkom University, Jl. Telekomunikasi Terusan Buah Batu, Bandung 40257, Indonesia \\ ${ }^{2}$ Istanbul Gelisim University, Avcilar/Istanbul 34310, Turkey \\ Correspondence should be addressed to Anton Abdulbasah Kamil; akamil@gelisim.edu.tr
}

Received 7 December 2020; Revised 15 February 2021; Accepted 23 February 2021; Published 5 March 2021

Academic Editor: Mehdi Keshavarz-Ghorabaee

Copyright (c) 2021 Endang Chumaidiyah et al. This is an open access article distributed under the Creative Commons Attribution License, which permits unrestricted use, distribution, and reproduction in any medium, provided the original work is properly cited.

\begin{abstract}
Different types of site selection exploited by geographic information systems (GIS) by combining various types of data relate to the purpose of site selection. In reality, numerous factors including physical, environmental, and social factors affect the site selection in terms of deciding the location of a new industry. Accordingly, this paper conceives systems for determining new industrial zones in the form of web-based applications or ordinarily called web-based GIS. Thus, the application named the potential industrial zone smart systems, in which the prototype of the application is able to facilitate planning the determination of new industrial zone based on six parameters throughout the analytical hierarchy process method. The result weights of six criteria are soil type $35 \%$, land use $32 \%$, land slope $15 \%$, the distance of land to river $9 \%$, the distance of land from road and accessibility $5 \%$, and the distance of land to public facilities $4 \%$. Additionally, the web-based GIS is a user-friendly application to determine the planned industrial location. Further, the demonstration runs effortlessly in exhibiting data on the potential of new industrial zones in the city of Bekasi, West Java Province of Indonesia.
\end{abstract}

\section{Introduction}

Determining the location of industrial zones has an important impact on various parties, including the government, industrial estate developers, and business actors in increasing the economy. The performance of the industrial area of the country in the ASEAN region for example looks more attractive than other countries for foreign investors. In Indonesia, there are 172 industrial estates, but few are attractive to investors, one of which is the Jababeka industrial area located in Bekasi, West Java. Therefore, it needs to be made optimal planning in determining the location of an industrial area by considering various aspects quickly by using computer applications.

Geographic information system (GIS) is a method that consumes spatial aspect in an application for multiple purposes. GIS works with spatial data using earth coordinate as reference. Also, GIS is beneficial to capture, save, develop, manipulate, analyze, and present all spatial data $[1,2]$. Generally, GIS is resulted from for a specific purpose, for instance, location selections [3]. In addition, GIS method is identical to combining several different layers and then analyzing it to achieve the goal. By utilizing GIS, the cost for identifying a large area could be minimal without abandoning several factors that give significant impacts in analysis results.

GIS for the location selections has a lot of uses for selecting new industry locations $[4,5]$. Several factors are affecting the location selections of new industries such as economic, social, physical, and environmental aspects [6-8]. Likewise, disaster risks, water availability, conservation area, and prohibited area are the examples of physical and environmental factors that affect industry locations $[9,10]$. Social factors impacting the selection of industry locations are labors availability, administration, politics, etc. Nowadays, GIS for new industrial locations turns into being more detailed and specific. 
Furthermore, the development of GIS study for the earlier 5 years has focused on parameter determinations. Also, the improvement of parameter determinations consists of a combination of physical, social, and population aspects [8]. Likewise, the selection of new industrial locations would be optimal through macroanalysis with complex parameters. On the one hand, the influence of the industrial revolution 4.0 era has changed the perspective of GIS as location selections method to be more specific [11-13]. On the other hand, it accommodates industrial development that is more dynamic.

In addition, the industrial area location determination must consider a soil type and its characteristic to have proper infrastructures. Neglected soil erosion and soil degradation lead to hazard for the environment and affect the area that is economically unproductive [14-17]. Soil properties are a part of important and detailed civil engineering study such as the determination of foundation type and soil capability to support industrial building and infrastructure.

Moreover, this study suggests scientific contributions as follows: (1) a comprehensive model of assessment systems for suitable industrial locations is proposed, and (2) it also proposes to design a smart system for selection of an industrial zone and (3) becomes an evaluation system of current predetermined industrial estates consistent with the industrial location theory.

\section{Literature Review}

2.1. Industrial Zone. The industrial zone is an area or special area designed to create an appropriate environment to sustain business operations. Also, a beneficial business environment is an environment that could optimize business continuity from upstream to downstream. Likewise, land usage for the industrial estate is a significant factor in increasing economic growth and economic development [18-20]. Therefore, the industrial zones function to enhance business and develop locations, founding complex "new cities" with infrastructure that supports business activities.

Moreover, the preparation of public facilities and specific infrastructures is essential to promote a competitive industry ecosystem. For instance, the industrial estates and companies located in a particular circumstance might mutually generate an economic agglomeration. In fact, in an effort to support the development of an inclusive Indonesia, the government is trying to encourage the development of 14 industrial estates outside Java until 2019. Bekasi, one of the regencies/cities in West Java Province is the location of at least thirteen industrial estates, one of which is the Jababeka Industrial Estate, the largest industrial estate in Southeast Asia [21, 22]. In turn, the new industrial park, opened to create competitiveness and economic growth, is so-called "special economic zones" or SEZ [23].

Additionally, another estimation related to the industrial zone comes from the World Bank [24], confirming that the industrial area is a special area (plot of land) disconnected from densely populated urban districts and categorized definitely for the location of industrial facilities. Thus, the industrial area should have the appropriate infrastructure facilitation such as roads, electricity, water supply, and other utility services.

2.2. Geographic Information Systems (GIS). In essence, geographic information system (GIS) is a computer-based tool that serves to analyze, store, manipulate, and visualize geographic information [25]. A GIS-based area map as supported by the results of the statistical analysis could be beneficial to formulate predictions. Definitely, GIS is an indirect method to analyze the spatial dimension. Required the use of GIS are being integrated in a computer application so that other important factors can be easily added as a consideration.

In this case, a spatial analysis provides the basis for integration and data collection with the spatial scale and a different time dimension, while the exploratory spatial data analysis is a set of techniques to describe and visualize the spatial distribution, identify the location of a typical or spatial stranger, discover patterns of spatial association, clusters, or hot spots, and propose spatial regimes or other forms of spatial heterogeneity [26, 27]. Spatial modelling techniques, for example, the regression analysis, are applicable to include explicitly the mechanisms of an underlying spatial pattern.

2.3. GIS-Based Industrial Site Selection. Meanwhile, GIS analysis is one of the major and most influential phases of the life cycle of the infrastructure, which leads to the validity, correctness, and methods utilized in planning an industrial area. Some analyses performed by GIS are water distribution analysis, traffic management analysis, soil analysis, site feasibility analysis, environmental impact analysis, volume or water catchment area analysis, river or canal pattern analysis, and temperature and humidity analysis [28].

In addition, the GIS-based model is extensively convenient to point out the most suitable location for building the industrial zone. The study [29] prefers using seven parameters, i.e., the use of land, water, soil, wildlife, archaeological sites, roads, and power lines to decide on the industrial region of Sri Lanka. Generally, the criteria attribute values included in the multicriteria decision-making applications exploiting the GIS model. Likewise, suitability maps are created with the weighted overlay model that can easily describe the appropriate location as well as meet all the criteria.

Furthermore, another study [30], which discourses the optimal location for new industrial zones applying the GIS fuzzy method has been operating in Yazd Township, Iran. This study exploited nine criteria for site selection parameters, i.e., road, fracturing, railways, water resources, urban, mountain, farmland, area or protected land, wildlife, and slopes. The criteria consist of two categories: anthropological and geographical criteria. In this case, the study proposes that the GIS approach could collaborate with the fuzzy method.

Moreover, the selection of industrial locations is a strategic decision that involves technical, economic, social, environmental, and political aspects [31]. The decision- 
making process would require the right tools and allows for data collection, storage, and analysis to address the complex and diverse scenario. In turn, a study with an innovative and efficient approach in attaining the most appropriate solution constructs on a series of decision support systems that interrelate. For instance, the study might exploit seventeen criteria, i.e., surface water, groundwater, soil type, slope, natural hazards, eroded area, floods, forest, wildlife, wetlands, coastal areas, agricultural areas, public places, archaeological sites, access roads, access water, and road width [32]. The assessment of the criteria should involve expert estimations. As a result, this presents that the GIS approach is one method that could well cooperate with the decisionmaking process, on the one hand.

On the other hand, the fuzzy AHP methodology is also appropriate to decide the best warehouse locations of the four existing options for the availability of the supply chain in a special economic zone (SEZ) and the free trade zone (FTZ) in Iran. In this case, the utilized criteria are the ten parameters consisting of the transportation and connectivity, electricity, water, IT and telecommunications, the cost of land, tax incentives, market size, proximity to major markets, and the scope for market growth [33].

Essentially, the Industrial Revolution 4.0, which promotes energy savings and reduces labor costs, also brings about a transformation in the selection of land for industrial plants. For example, the study of criteria for selecting land of manufacture facilities in urban-rural areas, which would be necessary for Industry 4.0 locations, involves the effective spatial patterns [11]. The utilized criteria contain two types of new industrial zones. The first is the selection of organized industrial zones that have parameters such as labor quality, proximity to markets, grants, land prices, ease of transformation, proximity to housing areas, infrastructure, proximity to raw materials, proximity to schools and health services, additional facilities, water, energy, urban services, land suitability, and economic closeness between cities and industries. The second is zone selection energy resources and IT with fewer parameters, i.e., the closeness to the IT and telecommunications, energy, grants, ease of transformation, proximity to raw materials, additional facilities, opportunities and suitability of the slope, the price of land, and unsuitability for agriculture. But, in [11], mapping is done manually, whereas in this study, the process of mapping is done with a web-based application.

\section{Methodology}

The applied method in this study to determine the location of an industrial zone is the approach of geographic information systems (GIS) and analytic hierarchy process (AHP). Therefore, the specification of this study compared with the previous ones is the design of an application termed userfriendly potential industrial zone smart systems by means of six criteria parameters. They are weighted, assessed, and determined by the range of score in terms of the conditions of the existing area based on the expert estimation. In this case, the weighting is complete using the analytical hierarchy process (AHP) method as a criterion of assessment scores on the application. Also, the criteria and weights that are attained and exploited in the design of smart system applications for determining industrial zones are land slope, land use, soil type, the distance of land from road and accessibility, the distance of land to river, and the distance of land to public facilities, while the six criteria and weights restored on adjustments of the criteria are exploited in the previous studies, among others [34] and provisions [35].

In the meantime, the principle approach of geographic information systems (GIS) is in accordance with [36], considering geotechnical and construction of spatial models [37-39]. The design of the application rested on geospatial principles [40-42] as well.

As for the case study is aimed for testing and implementing the resulted application, where in Bekasi, Indonesia, the study evaluates the suitability of its land as an industrial area. Also, testing and simulation work on a smaller scope at the district level of Bintara, Bekasi, in order to evaluate the suitability of the land in terms of industrial areas. Likewise, the application undertakes testing to try clicking on a particular polygon point to determine the area of the polygon.

3.1. Systems Design. The formulation of the application initiates with a use-case diagram as a technique exploited in the development of software or information systems to encapsulate the functional requirements of the system. Further, the use-case explicates the communication between actor and initiator of the interaction of the systems itself with the standing systems.

The rules that apply in the potential industrial zone smart systems model are as follows (see Figure 1):

Users of the systems are more than one person

Users could not upload more than one data at a time Users simply have one identity

Users could delete uploaded data

Users could simply see the data that are if not a member

The potential industrial zone smart systems model has the following functions:

An admin of validation:

Login

Managers of data admin:

To enter new user data

To change user data

To delete user data

Manager of spatial data:

To view the spatial data

To upload spatial data

To remove spatial data

To find spatial data by city/county

The aforementioned use-case diagram illustrates how users interact with the systems. Therefore, the user systems comprise an administrator and visitors, in which the admin 


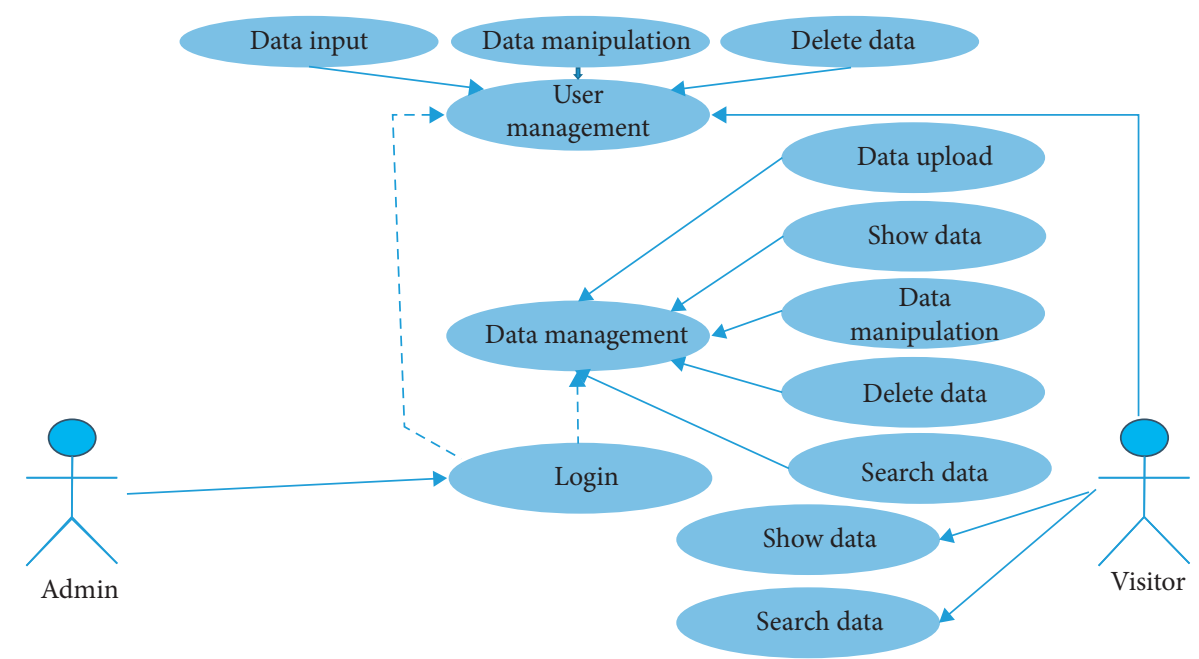

Figure 1: Use-case diagram.

can execute data management operations such as uploading and manipulating data, however, with the proviso must be the first login operation. Meanwhile, visitors could merely display and investigate data in the database system previously uploaded by the admin (see Figure 2).

3.2. Process Design. Furthermore, the potential industrial zone smart systems consist of three principal processes, which manifest in the data flow diagram (DFD) method, as seen in Figure 3, i.e., the setting up users (user management), data management, and process data display (show data). Additionally, the entire process appears in the configuration of maps and data by displaying variables such as slope rate, land use, soil type, distance to road and accessibility, distance to a river, and distance to public facilities.

However, the system administrators serve to the process of the user setting (user management), consisting of data input, data manipulation, and user data removal, see Figure 4.

Also, the admin controls on the process of the data setting (data management) comprise database management, data upload, and data deletion, see Figure 5.

3.3. Database Design. In the meantime, the provision of the database departs from the preparation of a data table variable, which is part of the process identification of the data in the database application as comprehended in Tables 1 and 2.

Therefore, all identified variables, subsequently, turn out to be the basis for designing variables relationship construct of the application. The arrangement of relationships among data in the development of the application is applying an entity-relationship diagram (ERD) as seen in Figure 6.

\section{Result}

4.1. The Weighting of Criteria. The weight calculation of the criteria used to determine the level of suitability of the location of the industrial estate using the AHP method obtained results is shown in Table 3. Data are extracted by

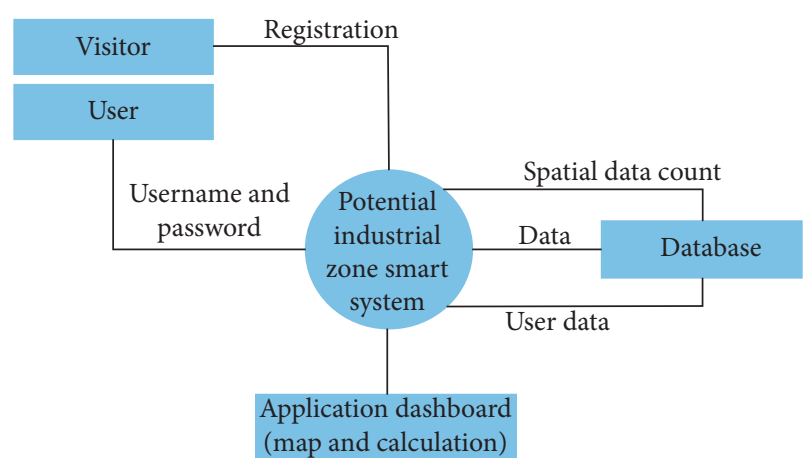

Figure 2: Context diagram.

pairwise comparison method with 3 expert respondents, so that the comparison between the level of importance of one criterion and another one is visible.

Calculation results of eigen vector, weighted sum vector (WSV), and consistence vector (CV) are used to determine $\lambda$ max and Consistency Index (CI). Random Index (RI), which is obtained from random table in accordance with 6 criteria that are being compared, is calculated as much as 1.24. Calculations of $\lambda$ max, Consistency Index (CI), and Random Index (RI) are shown in Table 4.

Consistency ratio value is obtained from division of Consistency Index (CI) with Random Index (RI). which obtained a consistency ratio value (CR) of 0.0872 . Because $\mathrm{CR}$ value $\leq 0.1000$, it can be concluded that the result of AHP criteria is consistent, so that it can be used as a consideration in decision-making.

The weighting of 6 criteria that are used to determine suitability of industrial zone location is shown in Table 5 successively from highest to lowest weight. These results show that soil characteristics such as soil type, land use, and land slope are used as the main consideration in determining the suitability of industrial location zone. After that, other criteria such as distance to river, distance to road, and distance to public facilities are used as the next consideration. 


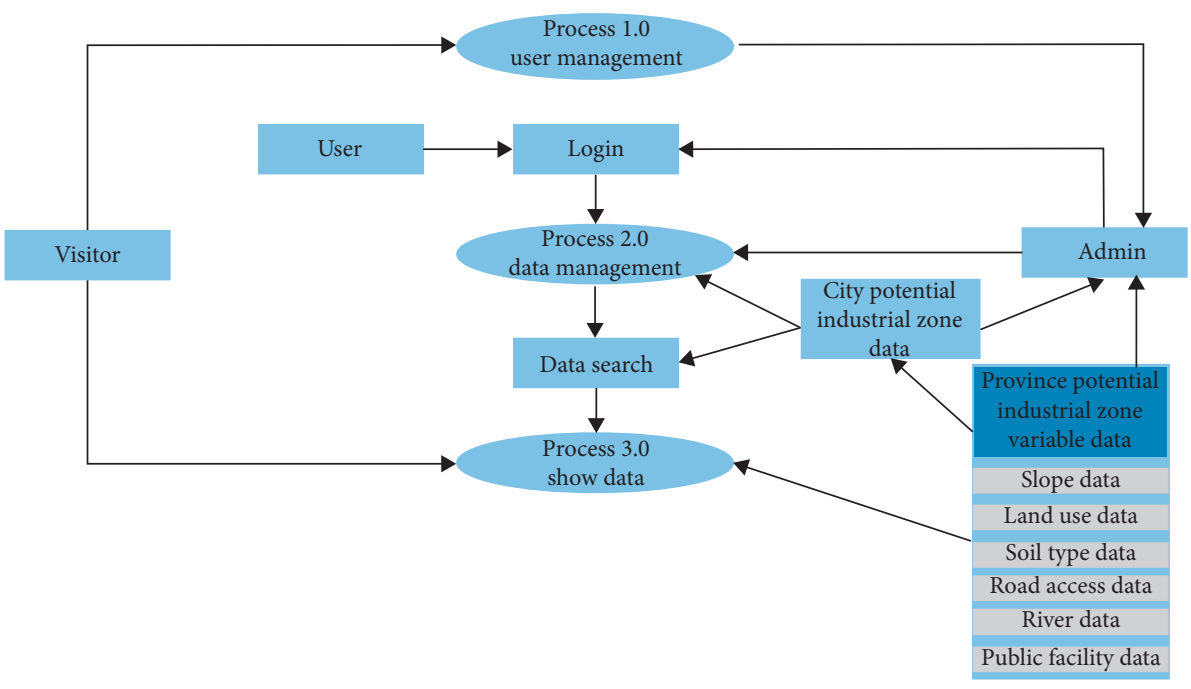

FIGURE 3: Main data flow diagram (DFD level 0).

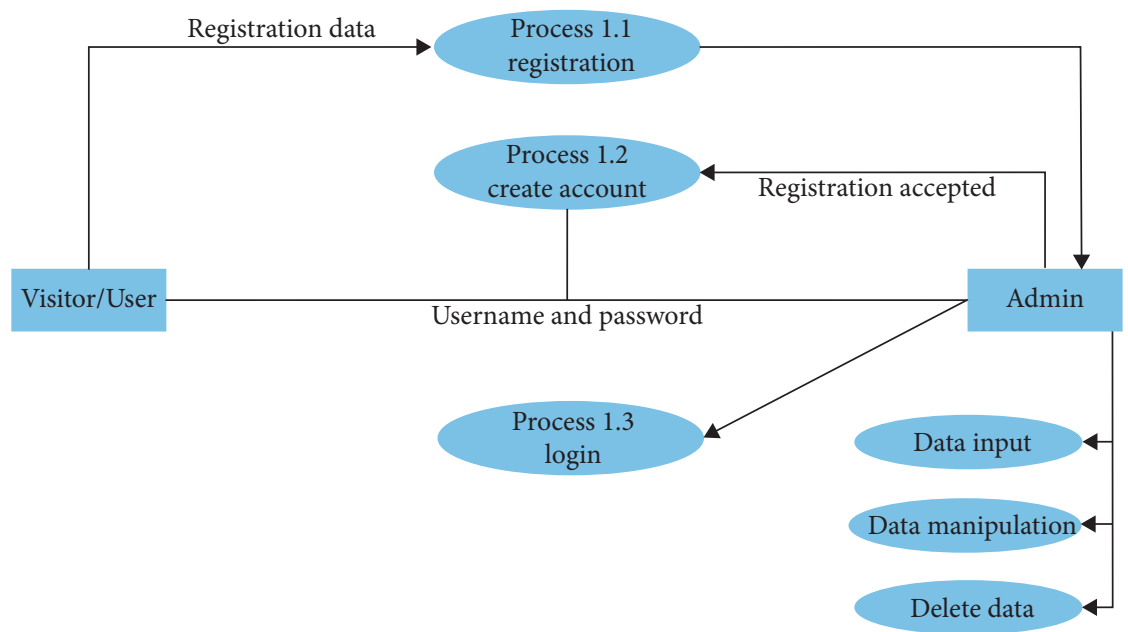

Figure 4: Data flow diagram user management (DFD level 1).

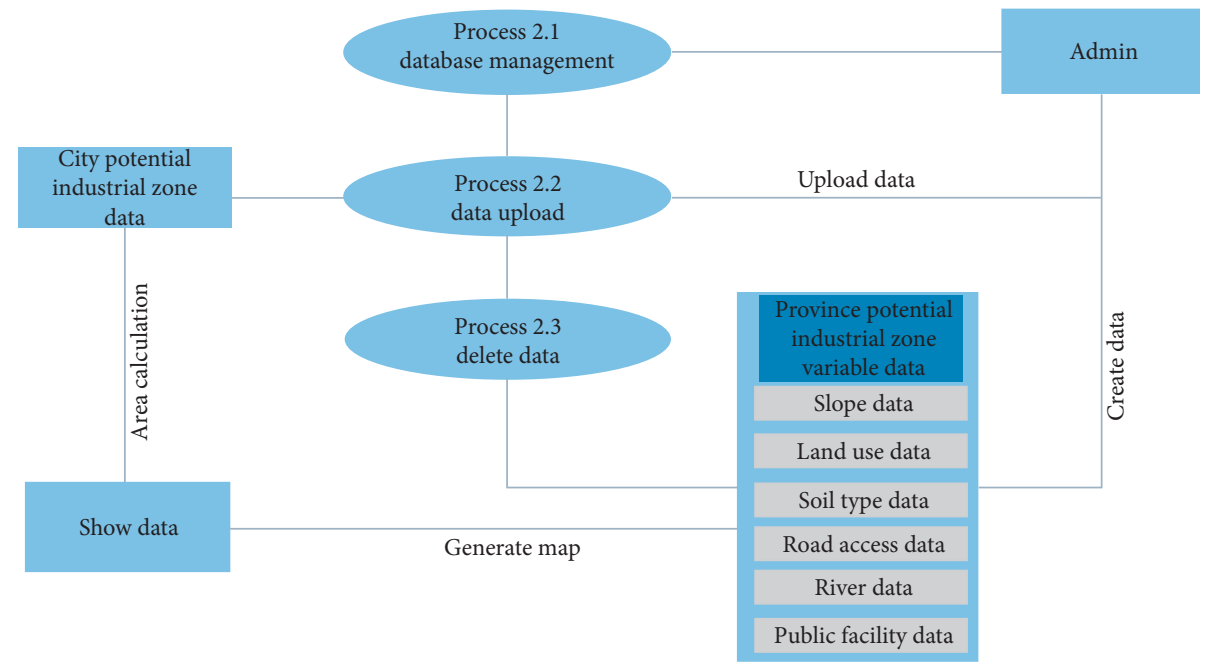

Figure 5: Data flow diagram data management (DFD level 1). 
TABLE 1: Data variable identification.

\begin{tabular}{lcc}
\hline No. & Attribute & Description \\
\hline 1 & ID & Unique identity in variable data \\
2 & Classification & Classification of variable data \\
3 & Class & Class of the suitability of variable data to the suitability of land for industrial zones \\
4 & Value & The value of a class of data variable suitability to the potential of the industrial zone \\
5 & Score & The score of a class of data variable suitability to the potential of the industrial zone \\
6 & Area & Calculates the area of an area in hectares and is useful to calculate the total area of the suitability level for a variable \\
\hline
\end{tabular}

TABLE 2: Variable data conformity industrial zone.

\begin{tabular}{ccc}
\hline No. & Attribute & Description \\
\hline 1 & ID & Unique identity in variable data \\
2 & Class & Suitability of all variable data on land suitability for industrial zones \\
3 & Total score & The total score of all classes of the suitability of variable data to the potential of the industrial zone \\
4 & Area & Calculates the area of an area in hectares and is useful to display the total area based on the class of suitability of all \\
variables to the potential of the industrial zone
\end{tabular}

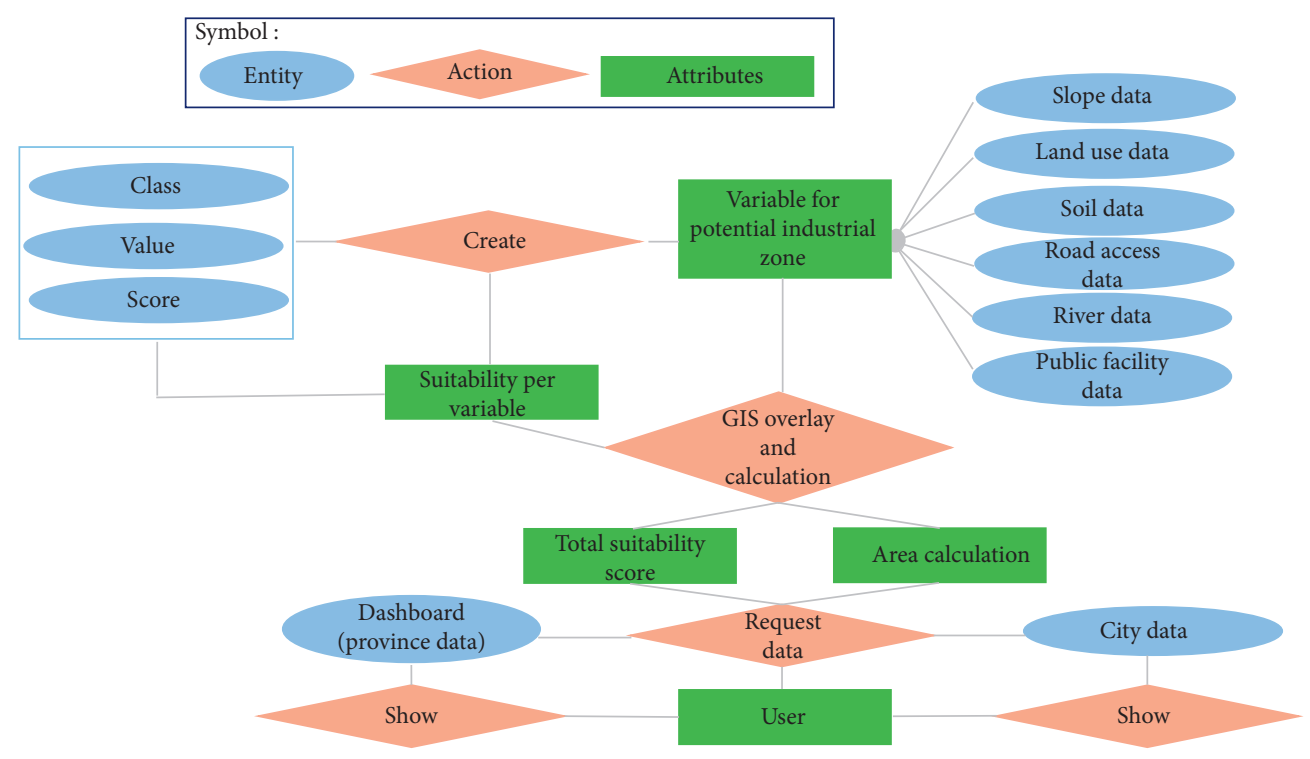

FIGURE 6: Entity-relationship diagram.

TABLE 3: Normalization.

\begin{tabular}{|c|c|c|c|c|c|c|c|}
\hline Criteria & Land slope & Land use & Soil type & Distance to road & Distance to river & Distance to public facilities & Total \\
\hline Land slope & 1.0000 & 0.3125 & 0.2326 & 1.6667 & 5.0000 & 2.5000 & 10.7117 \\
\hline Land use & 3.2000 & 1.000 & 1.4000 & 4.2000 & 3.2000 & 6.6667 & 19.6667 \\
\hline Soil type & 4.3000 & 0.7143 & 1.0000 & 8.5000 & 2.0000 & 10.0000 & 26.5143 \\
\hline Distance to road & 0.6000 & 0.2381 & 0.1176 & 1.0000 & 0.5000 & 1.0000 & 3.4557 \\
\hline Distance to river & 0.2000 & 0.3125 & 0.5000 & 2.0000 & 1.0000 & 2.0000 & 6.0125 \\
\hline Distance to public facilities & 0.4000 & 0.1500 & 0.1000 & 1.0000 & 0.5000 & 1.0000 & 3.1500 \\
\hline Total & 9.7000 & 2.7274 & 3.3502 & 18.3667 & 12.2000 & 23.1667 & 69.5110 \\
\hline Criteria & Eigen & WSV & $\mathrm{CV}$ & & & & \\
\hline Land slope & 0.1463 & 0.9683 & 6.6203 & & & & \\
\hline Land use & 0.3197 & 2.0677 & 6.4686 & & & & \\
\hline Soil type & 0.3497 & 2.2574 & 6.4552 & & & & \\
\hline Distance to road & 0.0523 & 0.3447 & 6.5955 & & & & \\
\hline Distance to river & 0.0894 & 0.5834 & 6.5275 & & & & \\
\hline Distance to public facilities & 0.0427 & 0.2811 & 6.5769 & & & & \\
\hline
\end{tabular}


TABle 4: Consistency ratio.

\begin{tabular}{ll}
\hline$\lambda \max$ & 6.5407 \\
\hline $\mathrm{CI}$ & 0.1081 \\
$\mathrm{RI}$ & 1.2400 \\
$\mathrm{CR}$ & 0.0872 \\
\hline
\end{tabular}

TABle 5: The weight of criteria.

\begin{tabular}{lc}
\hline Criteria & Weight (\%) \\
\hline Soil type & 35 \\
Land use & 32 \\
Land slope & 15 \\
Distance to river & 9 \\
Distance to road & 5 \\
Distance to public facilities & 4 \\
Total & 100 \\
\hline
\end{tabular}

4.2. Prototype Design. Furthermore, the study constructs a prototype application, which is beneficial to facilitate planners in establishing the new industrial zone as well as evaluating the existing industrial zones. The prototype is based on 6 criteria parameters, which is accessible through http://148.251.76.241/deta/dashboard.

Moreover, the major viewpoint of open source-based web map is an open street map (OSM), which is free of charge. The OSM presentation seems like a web map view of the Google Map application, see Figures 7 and 8. In addition, there are possibilities to use a basic map of both maps and satellite image with the switch over function located on the lower right of the application with the title "Satellite."

4.3. Software Operation. Also, the application benefited input data such as data format Google spatial or ${ }^{*}$.Kml or *.KMZ is the data format, which is sourced from a free application from the Google Earth, see Figure 9.

Likewise, the admin performs to upload all the typeformatted data and add to the layer types, so that it appears on the screen. Even if the uploaded data either appears on the screen or disappears by checking the checkbox in the Legend on the application. Similarly, uploading the data runs on Create Spatial Layer, which is on the left side of the application display, see Figure 10.

Moreover, the presentation of detailed data information appears to display through zooming in/zooming out (top left map) or search the location menus in terms of the location desired by the user, see Figure 11. As for seeing details of the data in a location, a user could click on the desired location to display.

4.4. City-Based Potential Industrial Zone. While the Select City drop-down feature is available just above the map to display the selected area or city to be displayed. In other words, the application would automatically accomplish the zoom function to the selected area. Also, the application would estimate and present the calculation of the selected area according to the grade level of suitability for the industrial zone.

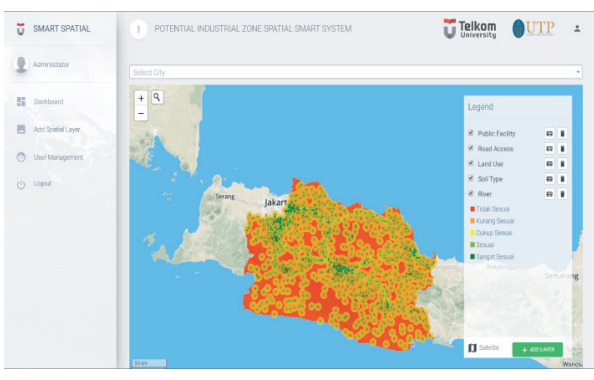

Figure 7: Application dashboard.

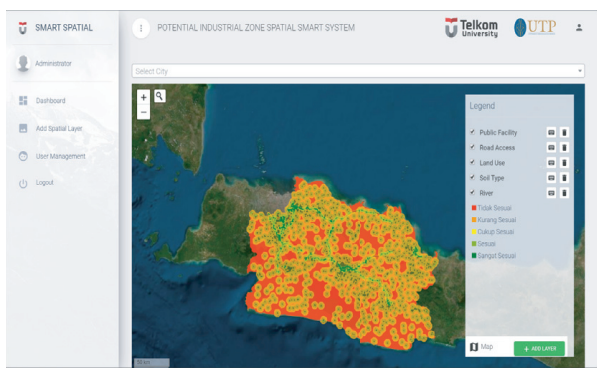

FIGURE 8: Satellite image (map background).

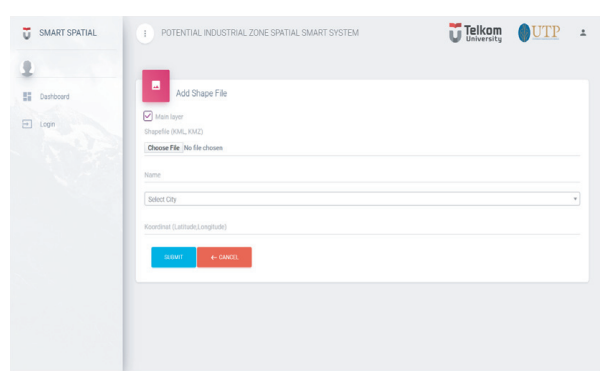

Figure 9: Input process.

The result of the design of the application is to present the location of a suitable area for an industrial zone designation based on the GIS analysis. Accordingly, the application would automatically estimate the total area with a score of suitability pertaining to an industrial location in a city. For example, Figures 12 and 13 demonstrate the inclusive total appropriate land for the industrial zone in Bekasi city.

In the meantime, in Bekasi city, the appropriate land for the industrial area was 21,267.69 hectares (98\%), while the inappropriate area was 337.72 hectares (2\%). As for each category, the assessment of conformity area for the industrial location of the most appropriate category is $18,967.83$ hectares; in an appropriate category, it is 1,269.18 hectares; in a quite appropriate category, it is 1,030.68 hectares; in a fewer appropriate category, it is 37.76 hectares, and in the inappropriate category, it is 299.96 hectares.

In addition, the application is able to estimate and trace automatically, with the purpose of retrieving the desired location. For example, by entering a phrase of the District of Bintara, Bekasi, the search column would directly go to the Bintara area. In other words, the simulation is performed to find out areas that are in the category of less appropriate for 


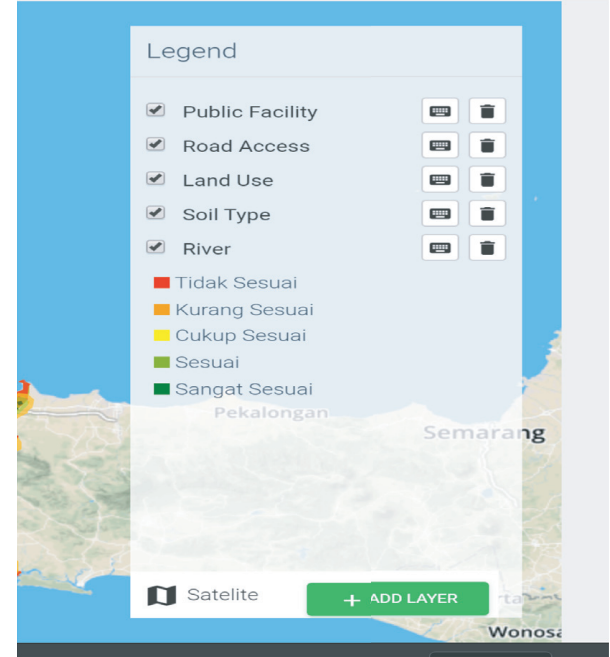

FIgURE 10: Data configuration.

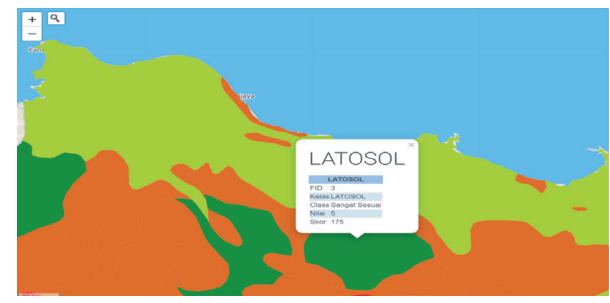

Figure 11: Presentation of detailed data.

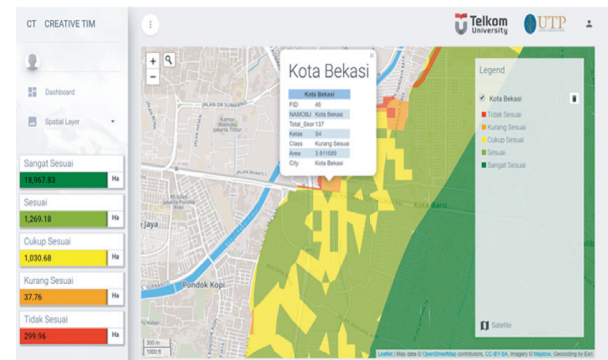

Figure 12: City location analysis process.

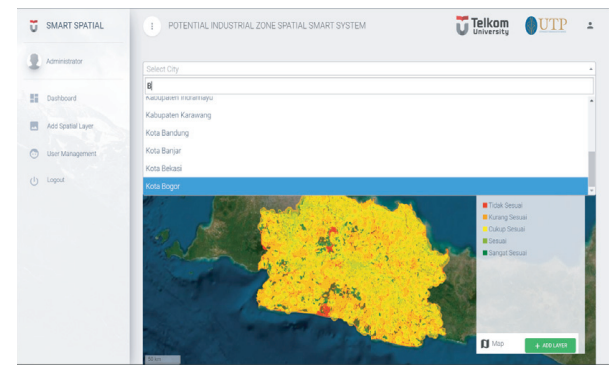

Figure 13: Bekasi city assessment analysis process.

industrial zones in the Bintara area. Click on the map, it will approximately display data of that area on certain polygons.

As for example, exhibited in the Bintara area, the location designated for polygon 1 on the map has an area of
3.91 hectares. As for the complete area in Bintara subdistrict, which has a land suitability score for the industrial zone, it is 137 hectares.

\section{Conclusion}

Therefore, the geographic information systems-based web design is convenient to enable users to determine the location of the planned industrial zones. The application is able to provide information of the GIS analysis of data with the determination of the new industrial zone so that users could decide the most potential locations in terms of a new industrial area.

Additionally, the presented information of the application is a data analysis of GIS-based six criteria parameters with both weights, which consist of soil type $35 \%$, land use $32 \%$, land slope $15 \%$, the distance of land to river $9 \%$, the distance of land from road and accessibility 5\%, and the distance of land to public facilities $4 \%$.

Meanwhile, demonstrations aim to disclose data about the potential of the new industrial zone in the West Java Province, which are per district. For instance, the results for Bekasi land appropriate for industrial areas are $98 \%$ and $2 \%$ is inappropriate. Hence, the application is also relevant to evaluate the stipulated industrial estate of the government decree with regard to the analysis and comparison with the potential area based on this spatial approach.

Also, users could upload data in a participatory means so that the others could benefit. In turn, this prototype is expectable in the future to be one platform to provide data in spatial planning with especially the determination of the industrial zone.

Certainly, the result of the application project is quiet in its early stages, which contain many complications so that in the future research, it needs to be refined. The improvement is especially in the data integration and the speed level searching for the location to let them perform faster. Likewise, the parameter criteria and the weights of the study are also quite likely to substitute for further research in the future such as economic, social, environmental, and technical research.

The limitation of this study is no environmental considerations for the effects of an industrial area on the ecosystem, such as the depth and vulnerability of groundwater, the prevailing wind direction, and water acceptor bodies of industrial wastewater.

\section{Data Availability}

The spatial data used to support the findings of this study are available from the corresponding author upon request.

\section{Conflicts of Interest}

The authors declare that they have no known conflicts of interest or personal relationships that could have appeared to influence the work reported in this paper. The spatial data used to support the findings of this study are available from the corresponding author upon request. 


\section{Authors' Contributions}

E. Chumaidiyah contributed to the original idea, methodology, and analysis. A. Abdulbasah K. contributed to data spatial analytic, and M. Rizka D. contributed to software and data collecting.

\section{References}

[1] A. Ricolavic, I. Cosic, and D. Lazarevic, "GIS based multicriteria analysis for industrial site selection," Procedia Engineering, vol. 69, pp. 1054-1063, Elsevier, 2014, http://www. sciencedirect.com.

[2] J. R. Eastman, H. Jiang, and J. Toledano, "Multi-criteria and multi-objective decision making for land allocation using GIS multicriteria analysis for land-use," Management Environment \& Management, vol. 9, pp. 227-251, 1998.

[3] P. Jankowski, "Integrating geographical information systems and multiple criteria decision-making methods," International Journal of Geographical Information Systems, vol. 9, no. 3, pp. 251-273, 1995.

[4] K. Eldrandaly, "Developing a GIS-based MCE site selection tool in ArcGIS using COM technology," The International Arab Journal of Information Technology, vol. 10, no. 3, 2013.

[5] J. Malczewski, "Integrating multicriteria analysis and geographic information systems: the ordered weighted averaging (OWA) approach," International Journal of Environmental Technology and Management, vol. 6, no. 1, pp. 7-19, 2006.

[6] R. L. Keeney, Siting Energy Facilities, Academic Press, New York, NY, USA, 1980.

[7] E. A. Williams and A. K. Massa, Siting of Major Facilities: A Practical Approach, McGraw-Hill Inc., New York, NY, USA, 1983.

[8] M. A. Badri, "Dimensions of industrial location factors: review and exploration," Jornal of Business and Public Affairs, vol. 1, no. 2, 2007.

[9] S. Hermann and E. Osinski, "Planning sustainable land use in rural areas at different spatial levels using GIS and modelling tools," Landsc Urban Plan, vol. 46, pp. 93-101, 1999.

[10] J. S. Jeong and Á. Ramírez-Gómez, "Renewable energy management to identify suitable biomass facility location with GIS-based assessment for sustainable environment," Energy Procedia, vol. 136, pp. 139-144, Elsevier, 2017, http://www. sciencedirect.com.

[11] G. Erdogan, "Land selection criteria for lights out factory districts during the industry 4.0 process," Journal of Urban Management, vol. 8, no. 3, pp. 377-385, 2019.

[12] M. Hermann, T. Pentek, and B. Otto, Design Principles for Industrie 4.0 Scenarios: a Literature Review, Technische Universität Dortmund, Dortmund, Germany, 2015.

[13] I. Fernandes and E. Assuncao, "Industry 4.0: training for automation in europe," Welding Journal, vol. 96, no. 7, pp. 50-52, 2017.

[14] V. Prasannakumar, H. Vijith, S. Abinod, and N. Geetha, "Estimation of soil erosion risk within a small mountainous sub-watershed in Kerala, India, using revised universal soil loss equation (RUSLE) and geo-information technology," Geoscience Frontiers, vol. 3, no. 2, 2011.

[15] S. K. Jain, S. Kumar, and J. Varghese, "Estimation of soil erosion for a Himalayan watershed using GIS technique," Water Resources Management, vol. 15, pp. 41-54, 2001.

[16] C. V. Srinivas, A. K. Maji, G. P. O Reddy, and G. R. Chary, "Assessment of soil erosion using remote sensing and GIS in Nagpur district, Maharashtra for prioritisation and delineation of conservation units," Journal Indian Society of Remote Sensing, vol. 30, no. 4, pp. 197-212, 2002.

[17] M. Kouli, P. Soupios, and F. Vallianatos, "Soil erosion prediction using the revised universal soil loss equation (RUSLE) in a GIS framework, Chania, Northwestern Crete, Greece," Environmental Geology, vol. 57, pp. 483-497, 2009.

[18] H. Akinci, A. Y. Ozalp, and B. Turgut, "Agricultural land use suitability analysis using GIS and AHP technique," Computers and Electronics in Agriculture, vol. 97, pp. 71-82, 2013.

[19] P. Mehta, Role of Industrial Development in Economic Growth, Economics Discussion, Washington, DC, USA, 2019, http:// www.economicsdiscussion.net/articles/role-of-industrialdevelopment-in-economic-growth/2227.

[20] M. P. Todaro and S. C. Smith, Population Growth and Economic Development:Causes, Consequences, and Controversies, Pearson Addision Wesley, Boston, MA, USA, 2012.

[21] Industrial Estate Directory, 2015/2016, A Guide for Investors, Indonesian Industrial Estate Association (Himpunan Kawasan Industri Indonesia), Jakarta, Indonesia, 2015.

[22] J. Octavia, Rebuilding Industrial Estates in Indonesia, Transformasi Center for Public Policy Transformation, Jakarta, Indonesia, 2016.

[23] Y. Saleman and L. Jordan, "The implementation of industrial parks, some lessons learned in India," in Proceedings of the Policy Research Working Paper 6799, Washington, DC, USA, March 2014.

[24] World Bank, Guidance Note on Tools for Pollution Management Getting to Green-A Sourcebook of Pollution Management Policy Tools for Growth and Competitiveness", The International Bank for Reconstruction and Development / THE WORLD BANK, Washington, DC, USA, 2012, http:// www.worldbank.org.

[25] R. F. Tomlinson, Thinking about GIS: Geographic Information System Planning for Managers, ESRI, Inc., Redlands, CA, USA, 2007.

[26] L. Anselin, "Exploratory spatial data analysis and geographic information systems," in New Tools for Spatial Analysis, M. Painho, Ed., Eurostat, Luxembourg, Europe, 1994.

[27] L. Anselin, "Interactive techniques and exploratory spatial data analysis," in Geographical Information Systems: Principles, Techniques, Management and Applications, P. A. Longley, M. F. Goodchild, D. J. Maguire, and D. W. Rhind, Eds., pp. 251-264, Wiley, New York, NY, USA, 1999.

[28] B. Das and D. Kumar, "Recent trends in GIS applications," SSRN Electronic Journal, 2015.

[29] G. M. T. S. Fernando, V. P. Sangasumana, and C. H. Edussuriya, "A GIS model for site selection of industrial zones in Sri Lanka," International Journal of Scientific \& Engineering Research, vol. 6, no. 11, pp. 172-175, 2015.

[30] A. R. K. Garmsir and M. R. Rezaei, "Selection of appropriate locations for industrial areas using GIS-Fuzzy methods. a case study of Yazd Township, Iran," Journal of Settlements and Spatial Planning, vol. 6, no. 1, pp. 19-25, 2015.

[31] A. Rikalovic, I. Cosic, R. D. Labati, and V. Piuri, "A comprehensive method for industrial site selection: the macro-location analysis," IEEE Systems Journal, vol. 11, no. 4, p. 2971, 2017.

[32] A. Rikalovic, I. Cosic, and D. Lazarevic, "GIS based multicriteria analysis for industrial site selection," Procedia Engineering, vol. 69, pp. 1054-1063, 2014.

[33] R. K. Singh, N. Chaudhary, and N. Saxena, "Selection of warehouse location for a global supply chain: a case study," IIMB Management Review, vol. 30, no. 4, pp. 343-356, 2018.

[34] A. I. Bagus Cahyadi, A. Suprayogi, and F. J. Amarrohman, "Penentuan Lokasi Potensial Pengembangan Kawasan 
Industri Menggunakan Sistem Informasi Geografis di Kabupaten Sukoharjo," Jurnal Geodesi Undip, vol. 7, no. 1, pp. 163-171, 2018.

[35] FAO, A Framework for Land Evaluation, FAOUNO, Rome, Italy, 1976.

[36] P. A. Burrough and R. A. McDonnell, Principles of Geographical Information Systems, Oxford Unviersity Press, Oxford, UK, 1998.

[37] L. Burt, Handbook of Geotechnical Investigation and Design Tables, CRC Press, Leiden, The Netherlands, 2014.

[38] J. P. Chiles and P. Definer, Geostatistics: Modeling Spatial Uncertainty, John Wiley \& Sons, Hoboken, NJ, USA, 2012.

[39] R. Chudley and R. Greeno, Building Construction Handbook, Routledge Tailor \& Francis Group, London, UK, 10th edition, 1998.

[40] M. J. Smith, M. F. Goodchild, and P. A. Longley, Geospatial Analysis A Comprehensive Guide to Principles, Techniques and Software Tools-Fourth Edition, The Winchelsea Press, Winchelsea, UK, 2007.

[41] R. K. Yin, Case Study Research: Design and Methods (Applied Social Research Methods), SAGE Publications, Thousand Oaks, CA, USA, 2009.

[42] E. Krause and Krivoruchko, Concept and Application of Kriging, ESRI, Redlands, CA, USA, 2019, http://proceedings. esri.com/library/userconf/proc15/tech-workshops/tw_29453.pdf. 